Journal of Chromatography, 342 (1985) 406-410

Biomedical Applications

Elsevier Science Publishers B.V , Amsterdam - Printed in The Netherlands

CHROMBIO. 2627

Note

Rapid gas-liquid chromatographic method for plasma verapamil level determination

\title{
U.A. SHUKLA
}

College of Pharmacy, The University of Michigan, Ann Arbor, MI 48109 (U.S.A.)

and

P.L. STETSON* and W.D. ENSMINGER

Upjohn Center for Clinical Pharmacology, The University of Michigan, Ann Arbor, MI 48109 (U.S.A.)

(First received September 18th, 1984; revised manuscript received March 15th, 1985)

Verapamil is a newly marketed antiarrhythmic drug. It has a significant presystemic elimination when administered orally and, therefore, intravenous therapy is often recommended. Optimum therapeutic effect is obtained when verapamil plasma concentrations are between 100 and $400 \mathrm{ng} / \mathrm{ml}$.

Several chromatographic procedures for the determination of verapamil in biological fluids have been described in the literature [1-11]. Some of the procedures have also quantitated verapamil metabolites $[1,6,7]$. The highperformance liquid chromatographic (HPLC), as well as the gas-liquid chromatographic (GLC) procedures are sensitive but require lengthy and tedious multiple extraction steps especially when the metabolites are quantitated.

This report describes a rapid, sensitive and accurate GLC procedure with thermionic specific detection for the determination of verapamil in dog plasma. This procedure also has a potential use in controlled clinical pharmacokinetic studies of this antiarrhythmic agent in humans.

MATERIALS AND METHODS

\section{Reagents}

Ethyl acetate, diethyl ether, pentane (Burdick \& Jackson Labs., Muskegon, 
MI, U.S.A.), sodium hydroxide (Fisher Scientific, Fairlawn, NJ, U.S.A.), verapamil hydrochloride (Knoll Pharmaceuticals, Whippany, NJ, U.S.A.), and 1-(diethylaminoethyl)-2-( -ethoxybenzyl)-5-nitrobenzimidazole $\cdot \mathrm{HCl}$, the internal standard, were used.

\section{Stock solutions}

Verapamil stock solution. Verapamil $\cdot \mathrm{HCl}(10.0 \mathrm{mg})$ was dissolved in 100 $\mathrm{ml}$ methanol to yield a stock solution containing $100 \mu \mathrm{g} / \mathrm{ml}$ verapamil $\cdot \mathrm{HCl}$.

Internal standard stock solution. Internal standard $(25.0 \mathrm{mg})$ was dissolved in $25 \mathrm{ml}$ ethyl acetate to yield a stock solution containing $1.0 \mathrm{mg} / \mathrm{ml}$ internal standard.

\section{Standards}

Verapamil standard solution. The verapamil stock solution was diluted 1:5 to yield a $20 \mu \mathrm{g} / \mathrm{ml}$ verapamil $\cdot \mathrm{HCl}$ standard solution.

Internal standard solution. The internal standard stock solution $(50 \mu \mathrm{l})$ was diluted to $5 \mathrm{ml}$ to yield a $10 \mu \mathrm{g} / \mathrm{ml}$ internal standard solution.

\section{Quality-control samples}

To a $25-\mathrm{ml}$ volumetric flask, $750 \mu \mathrm{l}$ of the verapamil standard solution (20 $\mu \mathrm{g} / \mathrm{ml}$ ) were added and the final volume adjusted to $25 \mathrm{ml}$ by addition of blank plasma. After mixing, $1.25-\mathrm{ml}$ aliquots were transferred to glass tubes, tightly capped and stored frozen at $-20^{\circ} \mathrm{C}$ until use. Each quality-control sample contained $600 \mathrm{ng} / \mathrm{ml}$ verapamil. Of the sample $1 \mathrm{ml}$ was used for analysis.

\section{Chromatographic conditions}

The gas chromatograph (Varian Model 3700) was equipped with a thermionic specific detector and a deactivated, silylated glass column $(1.2 \mathrm{~m}$ $\times 2 \mathrm{~mm}$ I.D., $6 \mathrm{~mm}$ O.D.) packed with $1 \%$ OV-1 on 60-80 mesh Gas-Chrom Q. The carrier gas was pre-purified nitrogen set to a flow-rate of $30 \mathrm{ml} / \mathrm{min}$. The air flow-rate to the detector was adjusted to $175 \mathrm{ml} / \mathrm{min}$ and the hydrogen flow-rate was set to $4.5 \mathrm{ml} / \mathrm{min}$. The bead current and bias voltage settings were 470 and 4 , respectively. The electrometer attenuation was set at $2-8 \cdot 10^{-11}$. The gas chromatograph operating conditions were: injector temperature, $280^{\circ} \mathrm{C}$, column temperature, $250^{\circ} \mathrm{C}$, and the detector temperature, $280^{\circ} \mathrm{C}$. The column was conditioned at $270^{\circ} \mathrm{C}$ for $24 \mathrm{~h}$.

\section{Sample preparation}

To glass tubes $(15 \mathrm{ml}$ capacity) were added $1 \mathrm{ml}$ plasma, $50 \mu 1$ internal standard solution, $50 \mu$ l sodium hydroxide $(10 M)$ and $7.5 \mathrm{ml}$ pentane-diethyl ether $(70: 30)$. The tubes were tightly capped and shaken for $15 \mathrm{~min}$. The tubes were then centrifuged at $1000 \mathrm{~g}$ for $10 \mathrm{~min}$ (room temperature) and $6.0 \mathrm{ml}$ of the organic phase (upper layer) were transferred to clean glass tubes and evaporated to dryness at $40^{\circ} \mathrm{C}$ with a stream of air. The residue was then reconstituted in $100 \mu \mathrm{l}$ ethyl acetate and $2.0 \mu \mathrm{l}$ were injected for GLC analysis. 


\section{RESULTS AND DISCUSSION}

Typical chromatograms of a calibration standard $(100 \mathrm{ng} / \mathrm{ml}$ verapamil), a pre-dose (blank) sample from an experimental subject (dog), and a plasma sample obtained from that subject after the intravenous (i.v.) administration of verapamil are shown in Fig. 1. Blank plasma did not have any interfering peaks as is evident from Fig. 1a. Retention times of verapamil and the internal standard were 1.7 and $2.5 \mathrm{~min}$, respectively. The validity of the assay procedure was established through a study of linearity of response, reproducibility, accuracy and precision.

Standard calibration curves corresponding to verapamil concentrations of $0.0,50.0,100.0,200.0,400.0,600.0,800.0$, and $1000.0 \mathrm{ng} / \mathrm{ml}$ of plasma were prepared by adding appropriate volumes of the verapamil standard solution to tubes containing $1.0 \mathrm{ml}$ blank plasma. The standard calibration curve was prepared by plotting peak height ratios (verapamil:internal standard) as a function of the verapamil concentration. The calibration curve was found to be linear over the verapamil concentration range of $50-1000 \mathrm{ng} / \mathrm{ml}$. The best-fit least-squares line was obtained by using a calibration curve program on the Apple II plus microcomputer. The data best fit a straight line. The correlation coefficients for inter-day standard calibration curves ranged from 0.9955 to 0.9989 . The coefficients of variation (C.V., \%) calculated from the inversely estimated concentrations for inter-day standard calibration curves ranged from $4.87 \%$ to $6.82 \%$. The intra-day reproducibility of the calibration samples had C.V. values ranging from $1.11 \%$ to $9.31 \%$ as shown in Table I.

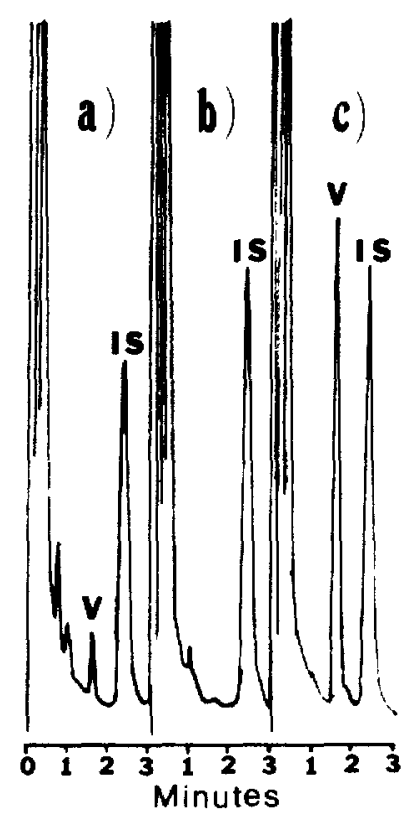

Fig. 1. Typical chromatograms representing (a) a calibration standard containing $100 \mathrm{ng} / \mathrm{ml}$ verapamil in plasma, (b) a pre-dose (blank) sample from the experimental subject (dog), and (c) a plasma sample obtained from the sane subject following the i.v infusion of verapamil $(0.267 \mathrm{mg} / \mathrm{kg} / \mathrm{min}$ for $3.0 \mathrm{~min})$. Peaks: V, verapamil; IS, internal standard. 


\section{TABLE I}

\section{INTRA-DAY REPRODUCIBILITY OF THE ASSAY}

Each peak height ratio was obtained from an independently prepared calibration sample; all samples were assayed on the same day.

\begin{tabular}{|c|c|c|c|c|c|}
\hline \multirow{2}{*}{$\begin{array}{l}\begin{array}{l}\text { Concentration } \\
(\mathrm{ng} / \mathrm{ml})\end{array} \\
50\end{array}$} & \multicolumn{3}{|c|}{ Peak height ratio } & Mean \pm S.D. & \multirow{2}{*}{$\frac{\begin{array}{l}\text { Coefficient of } \\
\text { variation }(\%)\end{array}}{9.31}$} \\
\hline & 0.147 & 0.176 & 0.170 & $0.1643 \pm 0.0153$ & \\
\hline 100 & 0300 & 0.300 & 0.294 & $0.298 \pm 0.003$ & 1.11 \\
\hline 200 & 0.500 & 0.609 & 0.579 & $0.582 \pm 0.0247$ & 4.24 \\
\hline 400 & 1.154 & 1.224 & 1.25 & $1.209 \pm 0.049$ & 4.10 \\
\hline 600 & 1.704 & 1.818 & 1.817 & $1.779 \pm 0.065$ & 3.68 \\
\hline 800 & 2.385 & 2.481 & 2387 & $2.417 \pm 0.0548$ & 2.26 \\
\hline 1000 & 2.758 & 3.08 & 2.963 & $2.9: \pm 0.163$ & 5.5 \\
\hline
\end{tabular}

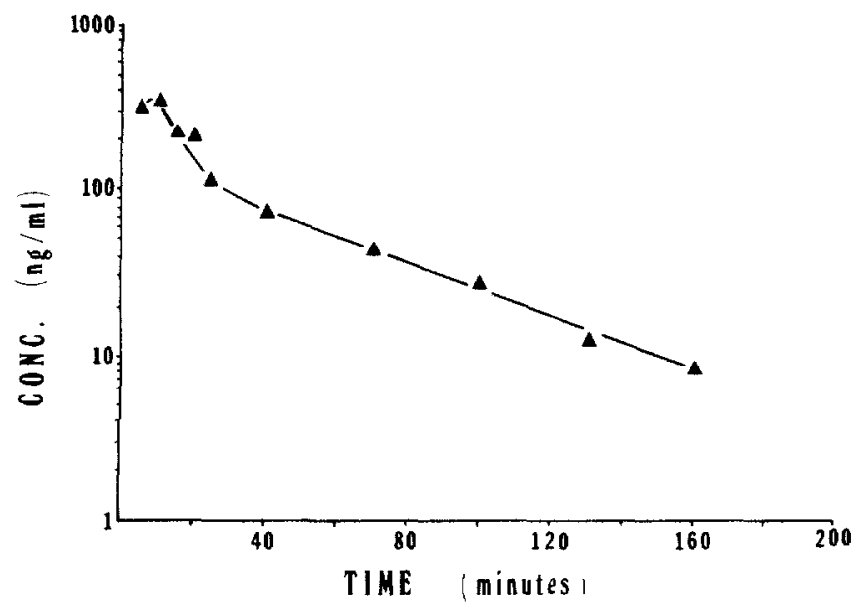

Fig. 2. The plasma concentration time profile in a dog following a short i.v. infusion of verapamil $(0.267 \mathrm{mg} / \mathrm{kg} / \mathrm{min}$ for $3.0 \mathrm{~min})$.

The accuracy of the method was assessed by analyzing quality-control samples on each assay day. The quality-control sample variability was found to have a C.V. of $9.26 \%$ and a mean concentration of $592.7 \mathrm{ng} / \mathrm{ml}$ with the theoretical concentration being $600 \mathrm{ng} / \mathrm{ml}$.

Application of the method developed was demonstrated by measuring plasma levels of verapamil in dogs after a short i.v. infusion of verapamil. The plasma concentration-time profile of verapamil obtained in one such pharmacokinetic study is shown in Fig. 2. The post-infusion data are well described by the following polyexponential equation:

$C=244.0 \mathrm{e}^{-0.1583 t}+125.4 \mathrm{e}^{-0.0177 t}$

The distribution half-life $\left(t_{1 / 2 \alpha}\right)$ of verapamil was $4.4 \mathrm{~min}$ and the terminal halflife $\left(t_{1 / 2 \beta}\right)$ was $39 \mathrm{~min}$.

Several analytical methods for verapamil determination require multiple extraction steps $\left[5^{-} 7,9,10\right]$ and are, therefore, time-consuming. The HPLC 
procedures described in the literature $[5,6,8-10]$ require longer chromatographic separation time as compared to the GLC method reported here. Several HPLC methods allow the determination of verapamil and some of its metabolites. However, only norverapamil has been shown to possess some biological activity. Although this method has not been applied for the determination of verapamil levels in clinical studies involving humans, the calibration samples and assay validation studies utilized both human and dog blank (control) plasmas interchangeably, and no interfering peaks were seen. The authors will be using this procedure for the determination of verapamil levels in plasma samples from a controlled clinical trial. Also, the sensitivity, precision and accuracy of this procedure compares well with those reported in the literature.

\section{REFERENCES}

1 B.G. Woodcock, R. Hopf and M. Kaltenbach, J. Cardiovase. Pharmacol., 2 (1980) 17.

2 J.A. Dominic, D.W. Bourne, T.G. Tan, E.B. Kirsten and R.G. Mc Allister, Jr., J. Cardiovasc. Pharmacol., 3 (1981) 25.

3 H.G. Hege, Arzneim.-Forsch., 29 (1979) 1681.

4 K. Nelson, B.G. Woodcock and R. Kirsten, Int J. Clin. Pharmacol. Biopharm., 17 (1979) 375.

5 S.R. Harapat and R.E. Kates, J. Chromatogr., 170 (1979) 385.

6 S.R. Harapat and R E. Kates, J. Chromatogr., 181 (1980) 484.

7 J. Vasiliades, K. Wilkerson, D. Ellul, M. Anticoli and A P. Rocchini, Clin. Chem. 28 (1982) 638 .

8 S.C.J Cole, R.J. Flanagan, A. Johnston and D.W. Holt, J. Chromatogr., 218 (1981) 621

9 V.K. Piotrovskii, D.O. Rumiantsev and V.I. Metelitsa, J Chromatogr., 275 (1983) 195.

10 M. Kuwada, T. Tateyama and J. Tsutsumi, J Chromatogr., 222 (1981) 507.

11 G. Remberg, M. Ende, M. Eichelbaum and M. Schomerus, Arzneim.-Forsch., 30 (1980) 398. 